\title{
De-Radicalization Program for Children's Victims of Terrorism Act at Social Rehabilitation Centre Handayani
}

\author{
Muji Novrita ${ }^{1}$, Muhammad Syauqillah ${ }^{2}$,Jerry Marcellinus Logahan ${ }^{3}$ \\ \{mujinov@gmail.com ${ }^{1}$, muhamadsyauqillah@ui.ac.id ${ }^{2}$, jerrymarcellinus@yahoo.com ${ }^{3}$ \} \\ 1,2,3 Terrorism Studies, School of Strategic and Global Studies, Universitas Indonesia, Jakarta - Indonesia
}

\begin{abstract}
The phenomenon of children who are exposed to terrorism is increasing. The series of Surabaya suicide bombings in May 2018 has left issues on how a state must be present to tackle the involvement of children in acts of terrorism. Despite the number of children falling victims of terrorism suitable instruments to protect children are not yet available. The objective of this study is to show how the de-radicalization program towards children is conducted, starting from the process of identification, rehabilitation, reeducation and re-integration conducted in a safe environment. The de-radicalization process conducted under the Social Rehabilitation Centre for Children in Need of Special Protection (BRSAMPK), Indonesian Ministry of Social Affairs, that handle children exposed to acts of terrorism. The de- radicalization activity towards children involved in acts of terrorism are physical, psychological, and social treatment or rehabilitation, also health care. Second, psychosocial during the procedure and recovery. Third, to provide social assistance for children who come from a low-income family. Fourth, to provide protection and support during every trial process. Special protection for child victims of terrorism network is conducted through assisting, education, ideology education and nationalism values, counselling re dangers of terrorism, social rehabilitation, and social assistance for children who undertake social rehabilitation.
\end{abstract}

Keywords: Terrorism, Deradicalizationn, Children, Family, Stakeholder

\section{Introduction}

Children are precious assets of a nation's future. A country must be present in its growth and development process so that they could give investment for its' future. Every child has the right to life, to grow up, to develop and to obtain protection from violence and discrimination as it is mandated in the 1945 Constitution of the Republic of Indonesia (UUD RI Tahun 1945) (1).

The series of Surabaya suicide bombings that occurred in May 2018 (2) shook the world because of the facts that some of the offenders were women and children, as martyrs. It is true the expression that says terrorism is a crime that goes beyond humanity or we often call it as an extraordinary crime in which that makes terrorism as a crime against humanity. The Surabaya incidents have made us realized that there was an involvement of children in terrorist attacks, whether they were as executors, planners, field coordinators, and as sympathizers.

Involving wives and children as suicide bombers is a crime against humanity in which it impacts the community widely. This crime drives terrorism researchers, academics, law 
enforcement officers and policymakers to find a way to handle it. Terrorism creates social and psychological impacts like, for example, fear, threat, inconvenience, chaos, physical and mental suffering and even death.

Basically, children are believed born with good nature. Parents, families and community members influence values embedded within themselves. Similar to all philosophers centuries ago, Jacques Rousseau (1762) in Spera (2) provided better understanding re interactive socialization process in which parents try to transmit values, purposes, skills, and their attitude to their children.

United Nations Office on Drugs and Crime (UNODC) has a standard rule on how to treat a child as offenders or victims of a crime which is called "Bangkok Rule". This rule provides inputs on how a country should facilitate child victims of crime in detail. Unfortunately, Indonesian Law does not specify ways to treat child victims of terrorism (3)

Concerning state's institution in responding to issues re children involved in terrorism, the Director-General of Social Rehabilitation of the Ministry of Social Affairs, Edi Suharto, explains in their website https://ppid.kemsos.go.id/, four efforts taken by the government in providing special protection for children, as regulated in that law. First, fast handling, including physical, psychological, and social treatment or rehabilitation, also prevention of sickness and other health problems. Second, psychosocial assistance during the procedure and recovery. Third, to provide social support for children who come from a low-income family. Fourth, to provide protection and assistance during every trial process. Special protection for child victims of terrorism network is conducted through delivering education, ideology education and national values, counselling dangers of terrorism, social rehabilitation, and social assistance. In 2017, the statistic data showed that the Indonesian Ministry of Social Affairs (Kemensos) had protected 87 children who were deported from Syria because of their involvement with terrorism network. Children undertake social rehabilitation in a safe house managed by the Kemensos with a social rehabilitation period of three (3) up to twelve (12) months. Child protection from radicalism and terrorism is addressed to (1) Child victims, children who experience physical, mental, and economic loss suffering as the result of influence by radicalism and terrorism. (2) Child offenders, children who are alleged influenced by radicalism and conduct terrorism crime. (3) Child of terrorists, children whose parents perform terrorism crime. And (4) child Witnesses, children who could provide testimony to assist pre-investigation, investigation, prosecution, and court trial of a terrorism case in which they hear, see and experience themselves.

The rehabilitation centre for children called Handayani, a government's pilot project institution, is created to be the venue to do de-radicalization in the handling of child victims of terrorism. The objective of this study is to provide inputs re de-radicalization program for children starting from the process of identification, rehabilitation, re-education and reintegration outside of prison. This objective, later on, would be given to stakeholders of the deradicalization program for children exposed to terrorism at the BRSAMPK Handayani.

\section{Theoretical Frameworks}

\subsection{De-radicalization Program}

The Law No.5 of 2018 (4) explains that de-radicalization towards a person, as mentioned in paragraph (2) letter (a) until (d) is given through these following phases: 
a) Identification and assessment. A detailed explanation of someone's level of exposure is explained in this phase, including his involvement in a terrorist cell or network so that the level of his radicalism could be identified. Identification is the first phase of the de-radicalization program against suspect, family, and network that shows indication of being radical. This program is a part of de-radicalization, so it does not only identify the targets but also the process of de-radicalization has been applied. The identification and assessment phase is a crucial phase because the person cannot yet be called a terrorist or terrorist inmate. Identification, in which it is an initial phase of the program, its primary role is "to identify", and the State must conduct de-radicalization towards people who have "been identified" and have an indication of being radical.

The targets of this phase are family, main family members (father, mother and children) of the suspected terrorists. This family could be broadened into its closest ones (relatives) if there is an indication that has been radicalised or provide support to radical or terrorism actions. A network is a group identified as radical beliefs and actions towards its surrounding. The objective of this phase is to find out the level of terrorist suspects and their family's understanding and behaviour. This also includes the typology of their knowledge and religious behaviours. The network's nationality is also identified as a radical one.

Success indicators of this phase consist of a mapping of radical indicated ideology networks that available, the availability of data of re-radicalised indicated families and networks, and awareness towards radical indicated family and network concerning their beliefs and radicalism level is achieved. Strategies used in the identification phase are: involving victims of terrorism in the implementation of identification program and involving former terrorists who have passed the de-radicalization and have been proven and tested possessing religious thoughts that are not radical and have stated loyalty to the state.

b) Rehabilitation is a recovery or healing to decrease someone's radicalism level

Rehabilitation program in de-radicalization is a systematic effort to make a change of orientation from radical and violent ideology to an inclusive, peaceful and tolerant ideology; and also to conduct religious, personality and self-reliance development effort towards terrorist inmates and their family. The objective of rehabilitation is to make terrorist inmates aware of their mistakes, their radical beliefs and terrorism actions that they have had/done before. To make them aware of their radical beliefs, behaviour and actions. To modernize terrorist inmates and their family radical beliefs and behaviour into inclusive, peaceful and tolerant ones. To conduct religious, personality and self-reliance development effort towards terrorist inmates and their family.

c) Re-education is a mentoring or reinforcement of someone in order for him or her to leave his or her terrorism radical beliefs. Re-education intervention towards terrorist inmates and their family on this phase is conducted by providing mentoring that consists of religious mentoring, personality mentoring and self-reliance mentoring. This phase is the phase to strengthen the thought, understanding, and their moderate and open behaviour by providing enlightenment for terrorist inmates and their family re religion and social teachings that highlight the values of peace and tolerance.

In the re-education phase, the transformation of thought, understanding and behaviour is conducted to enlighten terrorist inmates, former terrorist inmates and their family about religious and national teachings that have the values of peace, tolerance and openness towards some differences in the religious, community and state life. The targets of this phase are terrorist inmates. The ones who have attended the rehabilitation program and obtain a recommendation 
to continue the re-education program and those who are going to be released but not yet getting advice to maintain the re-education program. Principal members of terrorist inmates' family that consist of husband, wife and children. This family could be broadened into its closest ones (relatives) if they are considered to indicate that they have radical beliefs or provide support to the radical beliefs or terrorism actions.

The purpose are to strengthen knowledge, moral foundation of the terrorist inmates and their family in relation to their understanding and behaviour. To give them enlightenment, a peaceful, tolerant and open-minded religious teachings and also to respect differences and diversities. The indicators are the increase of terrorist inmates and their family's understanding and moral awareness. The change of thought, belief and radical behaviour of the terrorist inmates, former terrorist inmates and their family from radical one into open and tolerant thinking and uphold the religious and human values. The strategy is to put forward effective approaches and dialogues. They are involving former terrorist inmates who have recovered or are aware (having moderate thinking and nationalism commitment).

d) Social re-integration/re-socialization is a series of activities to de-radicalise people who have been exposed to radical terrorism beliefs so that they would be able to return to their family and community. The social reintegration is the third step of the de-radicalization program that is primarily targeting former and current terrorist inmates and their family. This resocialization program is intended to be an overall effort of former and current terrorist inmates and their family to be able to live and interact in their community. The scope of work of this resocialization program is not only limited to them but also to community members in which these people will live. In relation to children, former and current terrorist inmates with their main family members, husband, wife and children who are exposed to radicalism are vulnerable. This family could be broadened into its closest ones (relatives) if they are considered to indicate that they have radical beliefs or provide support to the radical beliefs or terrorism actions.

In the De-radicalization Blueprint, there are several approaches which are connected, continuous and in a systematic order to form a unity for de-radicalization effort.

- Ethical approach: ethical attitude in the context of de-radicalization emphasises that all religions teach their believers to perform love and affection to one another. This process includes the value of each religion in which to teach all believers to live peacefully together. There is no single religion that teaches its believers to act anarchy and to spread terror. This ethical approach encourages and believes that all religions are in line with all human values, to plant ethical values within themselves and to other people, values in the community and values in the future of their believers. This religious approach is strategic in the de-radicalization because religions are positioned as views of life.

- Psychological Approach, the de-radicalization concept in psychological approach is a step taken to change a hardcore behaviour and point of view into a soft, tolerant, peaceful, and moderate one. This approach is used to enable us to touch and understand the deepest parts of each person or a group. Also, by using this approach, we would be able to read and analyse aggressive behaviour, individual or group violence caused by internal self-factors like for example, personality, attitude, self-concept, ideology, etc. Meanwhile, there are some examples of external factors; like for instance parenting in the family, group pressure that is developed into self-identity in a social group and conformity behaviour, stimulation and provocation in their social environment. This approach could provide fast and accurate handling contribution and several guidances re psychological support methods. 
Souris \& Singh (5) stated that de-radicalization program is implemented by putting forward the psychological roles. A comprehensive and psychological-based framework would make this de-radicalization program more effective. It would be able to offer fundamental roles for the government and to protect the legal rights of former extremists. There are five approaches to implementing de-radicalization:

Social-Cultural Approach. De-radicalization could be implemented based on local wisdom. Local wisdom in the form of ideas, values and local point of views in which their nature are wise, full of wisdom and have ethical values. With those, violence and terror actions are expected able to be controlled. Local knowledge also could guide behaviour that determines civilization, like for example goodness, politeness, honesty, tolerance, respect and valuation towards other people, especially with those who have a different perspective, religion, tribe and other things.

Economic Approach is one of the practical approaches in empowering former terrorist inmates and their family. Economic empowerment creates self-reliance and welfare for them. Some studies show the link between poverty and terrorism, in which debt is one of the factors where radicalism and terrorism grow and develop.

Legal Approach. The purpose of the legal approach use in the implementation of the deradicalization program is to provide law assurance. This might include the drafting of a law to narrow down the spread of terrorism ideas and actions. The de-radicalization law is expected to empower in nature than as a repressive action, so that identification, rehabilitation, re-education and re-socialization could be accommodated comprehensively and proportionally.

Political Approach is meant to be a realization of de-radicalization in a list that gains a strong political legitimacy. This approach will create a comprehensive policy towards the development of the de-radicalization program in the authority order and its implementation.

Technology Approach. The development of technology and communication could be exploited as instruments to do de-radicalization. The printed version and electronic version, social media, social networking could be easily accessed. The technology could assist in doing counter-ideology, counter-narration, and to spread positive and constructive information accurately to a broader community. An approach should be conducted as one of the measures to reduce the intensity use of technology exploited by radical groups.

Meanwhile, in the de-radicalization blueprint, the main objective of the De-radicalization program is to change an individual's radical ideology or understanding into a moderate one by breaking down his or her knowledge of the fundamental teachings. There are seven objectives of the De-radicalization program.

- To mentor terrorist inmates in handling their radical terrorism view, thought, behaviour and action through the religious, social, cultural and economical approach.

- $\quad$ To enlighten their thought with a peaceful and tolerant religion and knowledge about nationalism in the framework of Unity Republic of Indonesia (NKRI).

- To develop terrorist inmates' self-reliance in the form of providing skills, expertise, and mentoring of their expertise.

- $\quad$ To prepare them before they are released back to their community and live together with other community members. 
- To mentor and empower terrorist inmates' family and community members to welcome them back so that they could re-socialize.

- To empower former terrorist inmates, their family and community members by using religious, social, education, cultural and economic approach, and;

- To empower community members to leave behind all radical terrorism belief and behaviour that develops in the community.

\subsection{Phases of a Child Development}

According to Sarwono (6), who previously studied ten former terrorists, the underlying issue of terrorism is a potential aggressiveness that has been planted since childhood and not because of brainwashing result. Analysis refactors that encourage terrorists to join a radical organisation is conducted During an interview; it is found that trauma that they have, make them join militant groups. In that extremist group, they found a father figure in the person who was the leader of that radical group. Another factor is because of self-esteem, and the last one is because of family background in which they have a fundamental religious experience. According to the previous study, in this study, the writer develops projections of a child psychosocial development using a child development theory and social bonding theory. In the context of parenting in a terrorist family, Fischer (7) conducts an experimental study that studies impacts of terrorism in the authoritarian practices, like for example parents, a father and a mother. It is found that terrorist threat (induced by the terrorist incident) has a significant impact on attitude and behaviour of authoritarian parenting practices, also towards actual conflicts in parents-children interaction. The implication of this finding, from the perspective of social psychological, re threat and parenting style, has an important meaning in the parenting context of terrorist family. Ali Fauzi states that the role of the family is vital in shaping the character and personality of a child (8).

Concerning personality and emotional development, Erickson (9) and Zuhdi et al. (8) state that "becoming" process is related to a critical period in human development. Erickson identifies eight phases in personality and emotional development, also with age estimation. The eight stages of personality developments are:

(i) the first year is trust vs. mistrust, first year,

(ii) the third year is autonomy vs. shame \& doubt

(iii) preschool-age on 3 to 6 years is initiative vs. guilt

(iv) age 6 to 12 years old is industry vs. inferiority,

(v) identity vs. confusion,

(vi) intimacy vs. isolation, young adults,

(vii) generativity vs. stagnation, middle adulthood),

(viii) integrity vs. despair, late adulthood).

Implications of each phase are as follows:

First, in trust phase, a child needs food and care. The child starts to recognise himself/herself, separated from other people. Understanding towards this reality makes trust aspect important. According to Piaget, this phase goes in line with sensorimotor skills in the intellectual development phase. Second, autonomy phase, a child learns to do something freely, or he or she might experience doubt if his or her senses could not manage the things around him or her. This phase is still in line with the sensorimotor stage. Third, the initiative vs guilt phase, a child learns to initiate exploration of his or her world. If he or she is unsuccessful at this phase, 
that may lead to the development of incompetence feeling. This phase is in line with the preoperational stage. Fourth, industry vs inferiority phase. A child tries to develop a sense of joy and pride when he or she is able to do or produce something from his or her activity. If he or she is not able to do or produce something, he or she will feel inferior. This phase goes in line with the concrete operational phase. Fifth, identity vs confusion. A child seeks and develops a personal character. He or she will try to find him/herself, or he or she might feel ambivalent towards his or her character.

\subsection{Social Bonding Theory}

Akers (10) states that social learning theory of crime and deviance to violent behaviour ranging from personal, individual violence to collective, terrorist violence, defined as illegal or illegitimate acts of physical threat and harm against persons and places by individuals or nonstate collectivises. While the principles of the theory apply to both conforming and deviant behaviour, for our purpose here, we do not include all acts of illegitimate violence, use of force, physical aggression, assault, homicide, rape, and property destruction in which injury or death is ignored.

On the other hand, Vygotsky's theory (11) on Social Bonding Theory on a child as a vision for early childhood education - re academic programs vs programs that focused on a child which suggest current responsiveness of children's capacity through putting forward the development. The key theme of Vygotsky approach toward early childhood education.

Social and Emotional Learning Theory is related to the involvement of parents or educators who want young people to succeed in their academic, personal, and social life. They want young people to have motivation and ability to achieve; to establish positive relationship with their peers or adults in their life; to adapt with complex demands on growth and development; to contribute to their peers, family, school and community; and to make a responsible decision that enhances their health and to avoid behavioural risks. As a response, many schools have adopted a program that targets one or more of problematic behaviour like violence or quit school from the beginning.

Behavioural issues that often caused by this program's target are overcome together in a group sharing the same risks and protective factors and could be overcome as a similar strategy. There is national support that develops for a comprehensive, coordinated approach to prevent (threats and positive activity promotion in the development of juvenile). School-based efforts, together with people in the family and in the community, have more significant influences. Those include environmental support so that children could get a chance to practice positive behaviour and accept consistent reinforcement.

\section{Methodology}

The research methodologies used are through observation and interview. Sources of data triangulation are conducted by researching the facts of certain information through various methods and data acquisition sources. For example, besides doing interviewing and observation, with participant observation, written documents, official records, personal notes and pictures or photos. These methodologies would produce contrary evidence or data in which further would 
provide different insights re-studied phenomenon. Those various insights would create the vastness of knowledge to obtain reliable facts.

Interviews were conducted in August and September in Jakarta and Lamongan. The stakeholders involved were BRSAMPK Handayani, mentoring staff from Special Detachment 88, National Counter-Terrorism Agency, Ustad and also the children of BRSAMPK Handayani.

\section{Discussions and Findings}

Until today, in Indonesia don't have a set of tools or instruments yet to play its role to deal with child victims of terrorism. The writer has conducted researches from several countries' actions on how they deal with a similar issue. There are some considerations of this literature study, which are differences of the social, cultural aspect, different psychological background. For example, Australia has empowered youth programs that are run by NGOs and children supervisors re Middle East immigrant children as violent offenders. In Indonesia, there are no immigrant children. Another standout difference is the social and psychological difference. For example, in the past, doing extreme violence using weapons and right-wing extremism background using religious ideology like what happens in Indonesia. There is not yet available suitable study, but from several studies, success is achieved in reviewing how to reduce radicalism on children and juvenile and to reduce potential terrorists in the future.

\subsection{De-radicalisation at BRSAMPK Handayani}

De-radicalization program at BRSAMPK Handayani is an Indonesian government pilot project in which it deals with children who are exposed to radicalism. This rehabilitation centre states that children are victims of parents' parenting style and also victims of the environment in which they cannot choose the situation. BRSAMPK is managed under Kemensos that has a legal basis in the implementation of its duty to protect children. Education and assistance given at this Centre are in the form of planned character education. Those who are educated who develop those children's potential so that they could bring benefits to themselves and other people.

$B R S A M P K$ Handayani's vision is to become the best partner in conducting social rehabilitation for children in need of special protection (CNSP). Meanwhile, the mission of the centre is to provide professional social services and to become a centre of study and a pilot project in handling children, to develop social networking, empowering CNSP, family, community members and social organisation/NGOs. Central Technical Implementer Unit and technical implementer unit of Directorate General of Rehabilitation of the Ministry of Social Affairs that carry out their duty to do social rehabilitation through provision of psychosocial therapy, physical therapy, mental and spiritual therapy also life skills therapy so that children would be able to be independent and actively involved in community.

Along with child protection phenomenon that increases every year, Social Minister's Regulation No 17 of 2018 on amendment of a house / panti amended into a center / balai, in which Social House of Marsudi Putra is changed into BRSAMPK Handayani which handles all clusters of CNSP according to Law No. 35 of 2004 amending the Law No.23 of 2002 on child protection article 59 (1). 
With that Social Minister's Regulation, BRSAMPK Handayani could provide social services and rehabilitation in a bigger scope in South Sumatera, Bangka Belitung, Lampung, the Special Capital Region of Jakarta, West Java, Banten, West Kalimantan and it becomes national and international reference for the handling of radicalism cases, trafficking, refugee, Indonesian child workers, and other child cases in an international scope.

There is not yet available a precise formulation on how to face complex child deradicalization programs. The de-radicalization process that includes identification, rehabilitation, re-education and re-integration is conducted at BRSAMPK Handayani in which it is based on the initiative of social resources, understanding about terrorism and how to handle a terrorist's child, de-radicalization program and BRSAMPK's budget in managing this child.

The writer compares the handling examples of child cases related to terrorism. For instance, child de-radicalization in Australia emphasizes youth empowerment programs more. Meanwhile, in the UK, the emphasis is more on how to handle a child who is related to rightwing extremism, especially IRA children. Parents, educators, law enforcement officers and health workers need to think about how to deal with child cases. A study conducted by Rousseau et al. (13) in the United States re the increase of shooting incidents at schools and concerning the threat, it is suspected going forward to violence activity. The 2018 study shows that more than $75 \%$ of US students need to be more supervised, to be early identified, and measures are taken to deal with students who are considered risky. With the consideration that there is no valid measurement or screening or detection tools to measure violence radicalism, children's damage and mistrust concerning their health, social service, and institutional education are considered more important in identifying the radicalised child.

Potential for a prisoner to be "de-radicalized" through psychological intervention and "reeducation is an interesting proportional, in which finally it could be successfully implemented in countries that have resources to provide programs that are adjusted consistently which fulfilled unique requirements of each case. To visit a prison in a corruptors' cell that is crowded, will not change one's view about the world in which the crime is conducted to promote or to defend themselves. Yet if a belief is based on an exclusive paradigm, the extremists are imprisoned because they have done something good. When the state agents have successfully interacted with those extremists in a personal level, by sharing family life stories, for example, a relationship could be established, and that will break their wrong assumption, and they would consider government as human beings too.

To enhance the success of the re-integration process after terrorist inmates are released, consistent meetings are needed. At this moment, the number of human resources at BNPT and parole service are not enough to fulfil this ideal requirement. Enhancing coordination with the organization of the local community, especially with a local government authority in a local and community level would help the officers since they could ask for their assistance. This would allow a well-organised communication. Individuals who are sentenced for terrorism in Indonesia are becoming ISIS supporters, and because of that reason, it is difficult to reach them. Except for cases with the death penalty, the tendency of these people would return to their community all over the world. Rehabilitation and re-integration are not the safest approaches to prevent further violence. Yet, to build a more coordinated and consistent system today, that absolutely will help in the future time.

Cook (14) gives an example of intensive training like that has a function to make children powerless against violence, and that would become "normalization". That kind of psychology and physical conditioning would make underage children adopt and even to compete to get the violence role in an organization like as a combatant, suicide operation, torturer, and slaughterer. ISIS young children are considered giving the organization tactical front line advantages. 
Children and juvenile are assigned to guard checking posts, to do espionage, to do reconnaissance, and weapons-making. They are considered "innocent". These children are also used as adult fighters' shields and as suicide attackers. There is evidence found that these children also take part individually and in a group.

BNPT's perspective on the implementation of de-radicalization towards children, the Deradicalization Director, Professor Irfan Idris ${ }^{1}$ emphasizes the use of psychological approach towards children. To use system manipulation of child development through mentoring, assisting and empowering. Children follow authority figures, who are parents, and they are not yet able to differentiate right and wrong. A State should assist and try to remove stigmatization/labelling a child as "a child of a terrorist". That child has to be treated as the state's child. If the state does not pay attention to this child development, there is a possibility that when he grows up, he will have ways of thinking like his parents.

The psychological approach is stated by Erickson (9) and Zuhdi, et al. (8). He said that "becoming" means is related to a critical period in human development. Erickson identifies eight phases in personality and emotional development, also with age estimation. The eight steps have been mentioned above. Children as inmates have a vulnerability in identity vs confusion phase (entering adolescence). They start to question their identity, whether they are part of the terrorist group or part of the community. Children seek and develop personal character. They try to find their identity, or they might feel ambivalent towards their identity. This phase is in line with the formal operational stage.

Implications of stage trust, children, need food and care. They start to recognise themselves, separated from other people or objects - understanding of this reality, making trust aspect relevant. At BRSAMPK Handayani, the children are provided with clothing, food and place to live. They also are given formal education inside the compound and assistance via a standby child psychologist in the Centre.

Ali Fauzi, one of the founders of Lingkar Foundation, a foundation that operates in the area of Control Flow Integrity (CFI), as one of soft approach media, utilises the Foundation to encourage former terrorists not to return to their terrorist networks and redo their terrorism actions. This Foundation is established with the purposes to eliminate traits, like bombings, to educate children, widows and wives whose husbands are still in prison for terrorism cases. In the interview ${ }^{2}$, Ali Fauzi emphasizes "vessel" or community empowerment for children and former offenders, children and widows so that they would feel comfortable and not easily giving up when they interact and live together with other community members. The Foundation assists the children by building Children Quran Recitation Place/Taman Pengajian Anak (TPA). They are educated with nationalism values, acceptance of differences and the mothers are given zakat money from the Founders of Lingkar Perdamaian Foundation so that they would be selfreliance. The objectives of these activities are to minimalize the possibility of them returning to their former terrorist networks and to prevent radicalism towards children and juvenile.

Activities conducted by the Lingkar Perdamaian Foundation are in line with Rousseau's Study on Muslim immigrants in the US, in which the result is to emphasize collaboration between professional medical staff, schools, and police officers. That is the key to overcome the

${ }^{1}$ Interview with Professor Irfan Idris (BNPT De-radicalization Director), at the $B N P T$ office, Ministry of State-Owned Enterprises/BUMN, Jl. Medan Merdeka Selatan No. 13, Gambir, Central Jakarta, on Friday, 23 August 2019.

${ }^{2}$ Interview with Ustad Ali Fauzi (Director of Lingkar Perdamaian Foundation), as one of the ustads who mentors child victims of Surabaya terror attacks. Conducted in Lingkar Perdamaian Foundation Gg. Masjid Baitul Muttaqien, Tenggulun, Solokuro, Lamongan District, East Java, on Saturday, 17 August 2019. 
social context of violence radicalization towards juvenile. Trust towards the community also determines the level of violent radicalization, the risks and benefits of intervention and prevention of radicalism on youth. Trauma that they have is the reason why they are involved with radical groups. They find a father's figure on their radical group leader - the need for selfesteem and the family background of radical belief. Based on the previous study, this study develops child psychosocial development projection with child development theory and binding social theory.

Most of the government would take the first safety approach to deal with terrorism threats in which they focus only on strict risk management. With that, an appropriate balance is expected to be achieved between social service and needed autonomy for individual reform on one side and to make sure the safety and security on another side. Risk assessment ideally should be conducted regularly starting from the arrest up to the release with evaluative input from various perspectives, from social to security and from the State to the civil society.

Interview result with Densus staff $^{3}$ and $B R S A M P K^{4}$, They explained the condition of child victims of Surabaya suicide bombings (A (15), D (13), F (11), H (10), Fa (9), Ai (8) and Hai (7)), who were accompanied by the mother of Wonocolo flat bombing (simple, low-cost apartment building) bombing offender. Initially, the role of grandmothers was sought since the children have been brainwashed not to believe people easily, especially police and government. They have considered them as thogut. The children were in fear, confused, and traumatized after seeing what happened. They lost their parents in the gunfight with police. One of them is a martyr (alive victim) of Surabaya City Resort Police Office/Mapolrestabes/ bombing conducted by her parents. They were also told that they would be brought to Jakarta to be killed by the government. After a year, BRSAMPK successfully has educated them the spirit of unity, socialization and nationalism as part of NKRI.

Ais (8) is the survival of suicide bombings conducted by her parents at Mapolrestabes Surabaya on Tuesday, $15^{\text {th }}$ of May 2019 (Merdeka.com). Ais survived the explosion, and she was thrown off 3 meters and was saved by Superintendent Ronny. Ais then admitted to Bhayangkara Hospital of East Java Regional Police and was recovered from psychological and explosion effect. After that Ais was taken care by BRSAMPK Handayani until today. Deborah Brown on Silke (15) states that child victims of terrorism like bombings, experience diverse impacts. They may have physical injuries that might need years to be healed. That is the same with to recover from its psychological trauma. Aish was upset knowing she has lost her parents. If those two issues, psychological and traumatic, are not able to be overcome, then there would be a tendency that the child would voluntarily join other terrorist groups (Machel, 2001 in Silke 2003). From this, it emphasizes that interaction between environmental factors with personality is proven, in which young people who have trauma would develop extreme behaviour.

A has been mentored and guided by BRSAMPK Handayani from the day of the incident until now. A has learnt and also has been assisted to deal with her trauma from the past using psychological and humanity approach. His needs as a child are fulfilled, and he is given a safe feeling. He also obtains decent education, and his friends support him to become a whole person. The handling of A, starting from the incident day, he was treated fast and obtained physical, psychological and social rehabilitation, also prevention of sickness and other health problems.

${ }^{3}$ Interview with Ustad Ali Fauzi (Director of Lingkar Perdamaian Foundation), as one of the ustads who mentors child victims of Surabaya terror attacks. Conducted in Lingkar Perdamaian Foundation Gg. Masjid Baitul Muttaqien, Tenggulun, Solokuro, Lamongan District, East Java, on Saturday, 17 August 2019

${ }^{4}$ Interview with Mrs. Neneng Hariyani (Head of BRSAMPK Handayani), PPA Bambu Apus Cipayung Street, Jakarta on Monday, 9 September 2019. 
Psychosocial assistance during treatment until recovery. Provision of social assistance for a child who comes from low-income family and rule of protection and support. Special protection for child victims of terrorism network is conducted through mentoring efforts; the State has fulfilled education, education about ideology and nationalism value, counselling about dangers of terrorism, social rehabilitation Social assistance for A.

De-radicalization approach conducted by Densus in assisting a child is to assist the child in facing trauma and also to obtain further information re the parents' network. One of the success indicators of de-radicalization is a child could provide information re his parents' network. The method used is to show pictures of Jamaah Ansharud Daulah (JAD) that haven't been revealed yet.

De-radicalization form towards a child that is focused on BRSAMPK for a child who is exposed to terrorism by focusing on child victims of Surabaya bombings. Kemensos staff at the BRSAMPK Handayani provide integrated assistance and service for children, physically, psychologically and spiritually. Human basic needs are fulfilled, starting from a comfortable, clean and healthy housing, clothes and food. The centre also has one child psychologist in the clinic who has a duty to assist a child's growth and development.

These seven children are sent to school in BRSAMPK complex with the intervention of integrated rehabilitation because each child is unique. They conduct humanist psychological approach and manipulation so that the kids would feel comfortable and able to deal with their past trauma and their family condition. These kids are encouraged to understand differences, to learn about public knowledge and religion by inviting Ustads to mentor them.

The trust relationship is mentioned again on Penal Reform International in 2015 that results in things that prevent and eradicate radicalism that might be beneficial for children. Children are able to participate in rehabilitation with some aspects, including: establish a relationship based on constructive trust with the staff; and develop future optimism after they are released through education development, training and work and connection with family and friends (as long as these are for their best interest).

The results of discussion of Service re Radicalism and Violent Extremism record that:

- Children rehabilitation takes time. Meanwhile, focusing on sports sometimes is a choice but not an effective one. Focus on art, theatre and music is also needed.

- Moroccan experience, radical targets are the smartest kids and assisting them to become leaders in the future.

- $\quad$ UNICEF has emphasized the importance of diversion and showing the five countries in that region that each already has a national action plan (Jordan, Sudan, Morocco, Tunisia and Egypt).

- Children friendly program should focus on protecting children from radicalism exploitation. Besides that, this program must also include mentors during imprisonment.

- Post-release, after treatment, (or is called a re-integration) program should be developed to respond to a group of inmates with a unique character to reduce the possibility of being recidivism.

In handling child cases of radicalism and terrorism, the psychological approach has also been mentioned by Bertelsen (12), or it is also called a Aarhus model implemented in Denmark. The anti-radicalization programmes and exit programmes from radicalism should focus on building resilience. Regarding the second set of moderating risk factors, that is, trying by means of education, dialogues, counselling or, in a few cases, also therapy to reform these factors of 
social cognition and social relationship from high-risk states to low-risk states. In the Aarhus Model, the Life Psychological model guides mentor training as well as the supervision of mentors working with specific cases e.g., how to identify risk factors and promote empowerment and resiliency according to the specific risk factors in the given case. Thus, Life Psychology is at least one way to theoretically and empirically underpin the idea of empowering individuals with fundamental human life skills, with particular reference to inclusion and legal participation in democratic processes and citizenship.

Sumpter (16) publishes 2014 UN Report that emphasizes the need of multi-discipline approach, that urges government to "to involve various actors, including civil society organization, private sectors, NGOs, family and community members. Memorandum from 2012 Global Counter-Terrorism Forum also emphasizes the strong partnership between the government, civil society, and community members, primarily to facilitate vocational skill training, higher education and continuous, supporting structure in the local level.

Environmental organization and community movement often have legitimacy and needed to involve people who might have released themselves from violence but still hiding their belief of anti-comfort and mistrust towards the state. Trade association on work vacancy also has to take a role in facilitating vacancies and chances to do a potential internship. Re-integration efforts are not only shown with social services and support. Considering national security implications from crimes conducted, the government could apply the restriction to those who have just been released. In the UK, when terrorist inmates serving their sentence because of terrorism cases and have completed it, before they are sent back to the community, they have to be assessed using a tool. as risk management tool called Arrangements of Multi-Agency Public Protection (AMAPP) is used to prevent recidivisms. AMAPP was initially designed for sexual abusers and violence offenders. Now, AMAPP is used to handle terrorist inmates, with additional restriction like limit the use of technology communication, restriction to do contact with certain people and organization, and the availability of worship place that is previously approved. According to Benediktus Wilkinson, AMAPP has been considered "successful enough in preventing serious recidivisms between terrorists, but this is not yet conducted in Indonesia.

Even though there is not yet a SOP, guidance or SOP to handle child victims of terrorism, BRSAMPK Handayani has an initiative together with other stakeholders, Densus 88, BNPT, NGOs (Csave) to do their best to deal with child victims so that in the future they will not be involved in terrorism activities and they will grow up to be whole persons. They might become agents of change for children returnees from Syria.

\section{Conclusion and Suggestion}

Indonesian state's presence in assisting children exposed to terrorism through the deradicalization program at $B R S A M P K$ is there. The state, in this context, is represented by BRSAMPK Handayani, BNPT, Densus 88 personnel and Children Supervisory Board, assist a child starting from providing psychological and social support also with their education. Deradicalization activities towards children related to a terrorism network are thriving at the fast handling stage. That includes physical, psychological and social treatment and rehabilitation also prevention of sickness and other health problems.

Psychosocial assistance is provided during the treatment and recovery phase. Social support is provided for a child who comes from a low-income family. Protection and assistance 
are also provided for every court trial. Special protection for child victims of terrorism is conducted through efforts like providing aid, education, ideology, nationalism value, counselling re dangers of terrorism, social rehabilitation, and social support for children who undertake social improvement at BRSAMPK Handayani. The process to return children to their community faces two challenges. The first one whether the family would welcome them back again or not and second, whether they would be re-connected with their parents' network or not. There is also a possibility of revenge from the bomb attacks' victims' family in which that would create a new conflict.

\section{References}

[1]. The 1945 Constitution of the Republic of Indonesia..

[2]. Spera C. A Review of the Relationship among Parenting Practices, Parenting Styles, and Adolescent School Achievement. Educational Psychology Review. 2005; 17(2): 125-146.

[3]. Huber A. Women in Criminal Justice Systems and the Added Value of the UN Bangkok Rules. In Kury HRSSE, editor. Women and Children as Victims and Offenders: Background, Prevention, Reintegration. Switzerland: Springer; 2016.

[4]. Law No. 5 of 2018 on on Amendment to Terrorism Law..

[5]. Singh SSE. Foreign Policy: Want to Deradicalize Terrorists? Treat Them Like Everyone Else. [Online].; 2018. Available from: https://foreignpolicy.com/2018/11/23/want-to-deradicalizeterrorists-treat-them-like-everyone-else-counterterrorism-deradicalization-france-sri-lankapontourny-cve/.

[6]. Sarwono SW. Terorisme di Indonesia: Dalam Tinjauan Psikologi Jakarta: Alvabet; 2012.

[7]. Fischer P,FJ,FD,SM,SM,TM,\&KA. Causal Evidence that Terrorism Salience Increases Authoritarian Parenting Practices Social Psychology. Social Psychology. 2010; 41(4): 246-254.

[8]. Zuhdi MSMea. Family Resillience: Radicalism Paradox in Indonesian Family. Jakarta : School of Strategic and Global Studies, Universitas Indonesia; 2018.

[9]. Brady L. Children and their Books: The Right Book for the Right Child. In Saxby M,WG, editor. Give them Wings: The Experience of Children's Literarure. Melbourne: The Macmillan Company; 1991. p. 26-38.

[10]. Akers RL,SA. Violence: From Theory to Research Zahn MBHJS, editor. New York: Routledge; 2004.

[11]. Berk LE,WA. Vygotsky Early Childhood Education Washington D.C: NAEYC; 1995.

[12]. Bertelsen P. Danish Preventive Measures and De-Radicalization Strategies: The Aarhus Model. Panorama: Insights into Asian and European Affairs. 2015; 1: 241-253.

[13]. Rousseau C,EHB,LJ. The Dilemma of Predicting Violent Radicalization. Pediatrics. 2017 October; 140(4).

[14]. Cook J,G. From Daesh to 'Diaspora': Tracing the Women and Minors of Islamic State. London: Department of War Studies, King's College London; 2018.

[15]. Silke A, editor. Terrorists, Victims and Society: Psychological Perspectives on Terrorism and its Consequences Chichester: John Wiley \& Sons; 2003.

[16]. Sumpter C,WYK\&PS. Testing Transitions: Extremist Prisoners Re-Entering Indonesian Society. Studies in Conflict \& Terrorism. 2019; DOI: 10.1080/1057610X.2018.1560666.

[17.] De-radicalization Blueprint. Jakarta: BNPT.

[18.] Preventing Radicalisation in Prisons: Developing a Coordinated and Effective Approach. Penal Reform International. 
[19]. Salari R,TC,SA. Parenting Scale: Which Version Should We Use? Journal of Psychopathology and Behavioral Assesment. 2012; 34(2): 268-281.

[20]. Bornstein MH. Parenting: Science and Practice. Parenting. 2001; 1(1 - 2): 1-4.

[21]. PPID Kemsos. [Online]. Available from: https://ppid.kemsos.go.id/.

[22]. Handayani Kemsos. [Online]. Available from: https://handayani.kemsos.go.id/.

[23]. Sasongko D. Merdeka.com: Ini kondisi anak pelaku bom Polrestabes Surabaya usai terpental 3 meter. [Online].; 2018. Available from: https://www.merdeka.com/peristiwa/ini-kondisi-anakpelaku-bom-polrestabes-surabaya-usai-terpental-3-meter.html.

[24]. Payton J.W. WDM,GPA,BMR,TCJ,WRP. Social and Emotional Learning: A Framework for Promoting Mental Health and Reducing Risk Behavior in Children and Youth. Journal of School Health. 2000; 70(5): 179-185 